\title{
Study on capacity of improved lithium iron phosphate battery for grid energy storage
}

\author{
Yan Bofeng, Zeng Ming \\ North China Electric Power University, Beijing 102206, China
}

Received December 20, 2018

\begin{abstract}
This article discusses the structure and use of cathode materials with iron phosphate ions. Improved iron phosphate nanoplates were obtained, their electrochemical properties were analyzed, especially in the case of direct current, their charge and discharge times were studied. The energy accumulator based on LiFePO4 was studied, the reliability of the results is confirmed by situational studies.

Keywords: Grid energy storage, lithium-ion battery; $\mathrm{LiFePO}_{4}$ capacity.

В статье рассматриваются структура и применение катодных материалов с фосфатионами железа. Получены улучшенные нанолистки фосфата железа, проанализированы их әлектрохимические свойства, особенно в случае постоянного тока, изучено их время заряда и разряда. Изучен накопитель энергии на основе $\mathrm{LiFePO}_{4}$, достоверность результатов подтверждается ситуационными исследованиями.
\end{abstract}

Дослідження ємності вдосконаленої літій-залізо-фосфатної батареї для зберігання енергіï. Yan Bofeng, Zeng Ming

У статті розглядаються структура і застосування катодних матеріалів з фосфатіонами заліза. Отримано поліпшені нанолистки фосфату заліза, проаналізовано їх електрохімічні властивості, особливо у разі постійного струму, вивчено їх час заряду і розряду. Вивчено накопичувач енергії на основі $\mathrm{LiFePO}_{4}$, достовірність результатів підтверджується ситуаційними дослідженнями.

\section{Introduction}

Along with the rapid development of the economy and the massive increase in energy demand, the serious environmental problems have aroused widespread concern in society. The clean energy represented by wind energy and solar energy has become an effective way to cope with energy crisis and environmental problems with its abundant reserves, safety and high efficiency. However, the randomness, intermittentness and volatility of clean energy make its largescale grid connection have certain risks. In order to improve the clean energy utilization rate and ensure the safe and reliable operation of the system, the energy storage device is used to improve the grid connection efficiency of clean energy, realize load shifting, and improve the contradiction between energy supply and demand [1]. Lithium-ion batteries have the advantages of low cost, good safety performance, high chemical stability and high thermal decomposition temperature, and are widely used in the field of energy storage, but the cycle performance of square lithium ion batteries is much worse than small cylindrical battery in large-scale energy storage. Unforeseen battery capacity loss and limited life span have significant commercial risks. For this reason, researchers at home and abroad have conducted in-depth research on lithium ion battery improvement, cycle and storage life.

At present, domestic and foreign scholars have carried out a lot of research work on the research of energy storage materials in clean energy power generation systems 


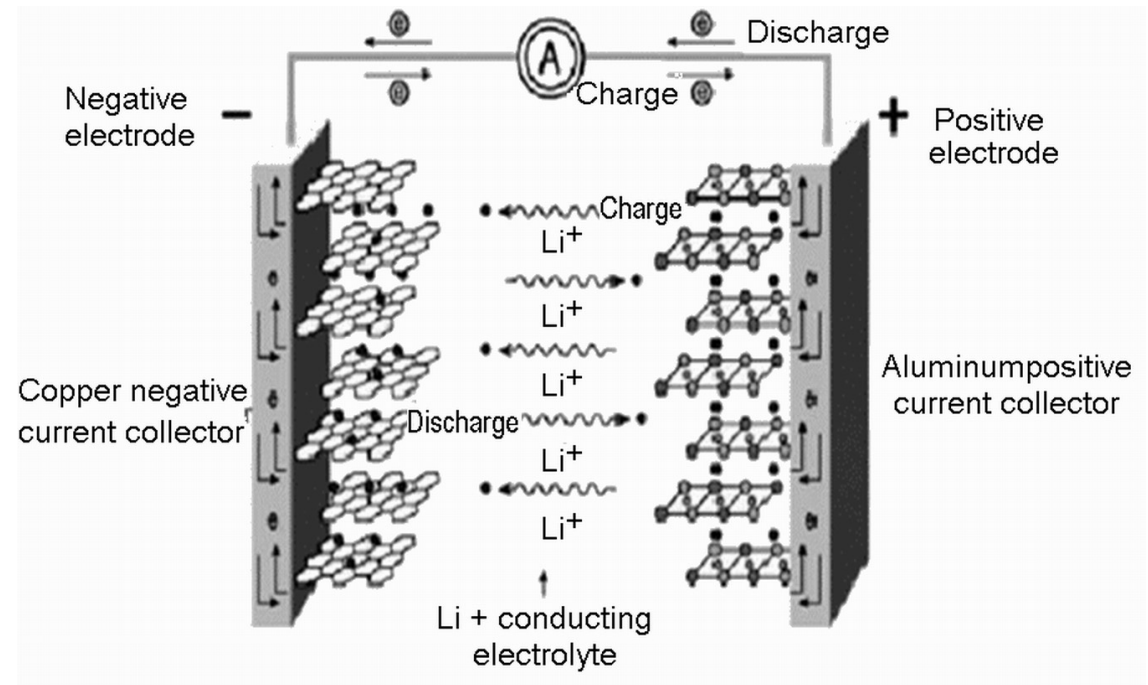

Fig. 1. Schematic diagram of lithium ion battery.

and made some progress. The literature [2] comparatively analyzes the basic performance parameters and applicable conditions of the current five different lithium ion cathode materials; the literature [3] proposes that the composite has excellent rate performance and cycle stability, and is an excellent lithium ion battery anode material. Literature [4] lists several types of energy storage batteries for grids and performs performance analysis. In [5], the photovoltaic and energy storage batteries are connected in parallel, and the unbalanced power is absorbed or supplemented by the lithium ion battery, thereby suppressing the power fluctuation of the grid connection; the literature [6] is equipped with a hybrid energy storage system composed of an energy storage battery and a super capacitor. Different filtering algorithms optimize the power distribution of the two energy storage devices, which improves the economics of the energy storage equipment. The study takes into account the technical and economical nature of energy storage equipment. Literature [7] introduces the battery and fuel cell into the photovoltaic discharge system at the same time, the short-term power fluctuation of the battery balance system, the high-energy fuel cell maintains the long-term power balance of the system, and improves the reliability and stability of the system; the literature [8] proposes the wind system. The energy storage capacity optimization problem is solved, and a two-layer decision model is established for this problem. The power fluctuations under different power generation modes are selected to analyze the effectiveness of the proposed model.
In this paper, the dynamic square lithium iron phosphate battery is taken as the research object. The structural stability, electrochemical characteristics and surface morphology of the positive and negative electrodes before and after the cycle are studied in depth. The energy storage capacity optimization model with clean energy is established, in which the cost and system stability are optimal, and finally a case study is performed.

\section{Energy storage techniques and characteristics}

Generally large-scale energy storage can be divided into mechanical energy storage (flywheel energy storage, pumped storage and compressed air energy storage), chemical energy storage (hydrogen and other chemical energy storage) and electrochemical energy storage (secondary battery and fluid) Battery) and other four categories. The energy storage characteristics of different energy storage methods are different. Among them, electrochemical energy storage has the advantages of high energy density, fast response time, low maintenance cost, flexibility and convenience, and has become the development direction of largescale energy storage technology. Electrochemical energy storage is the mutual conversion of electrical energy and chemical energy through electrochemical reaction, thereby realizing the storage and release of electrical energy. Since the birth of the Daniel battery in 1836 (zinc copper primary battery), battery technology has developed rapidly. Room temperature battery lead-acid 
batteries, nickel-chromium batteries, nickelhydrogen batteries, lithium-ion batteries and fluid batteries, high-temperature batteries such as sodium-sulfur batteries, sodium-nickel chloride and other development. Lithium-ion battery technology began with the lithium-encapsulated material proposed by Goodeneough. This material is still used today. Its chemical energy storage depends on the intercalation and deintercalation of lithium ions in the positive and negative electrode materials, as shown in Fig. (1). In 1991, Sony began the business process of lithium-ion batteries. Early lithium-ion batteries have greatly promoted the development of mobile electronic devices. However, the traditional lithium-ion battery safety and cost constraints are only used for small mobile communication devices, and it is difficult to meet the large-scale application of grid energy storage. In recent years, the development of lithium-ion batteries has focused on safety, colleges and universities, and low-cost cathode material replacement systems. In the $1990 \mathrm{~s}$, Padhi et al. first synthesized iron phosphate ion cathode materials, and the cost was greatly reduced, making it possible to use lithium ions for large-scale energy storage applications. The performance parameters of different lithium-ion batteries are shown in Table 1 . Under the background of large-scale industrialization of lithium-ion batteries, highenergy lithium-ion batteries will surely meet the large-scale energy storage needs of the grid, and usher in a better development prospect.

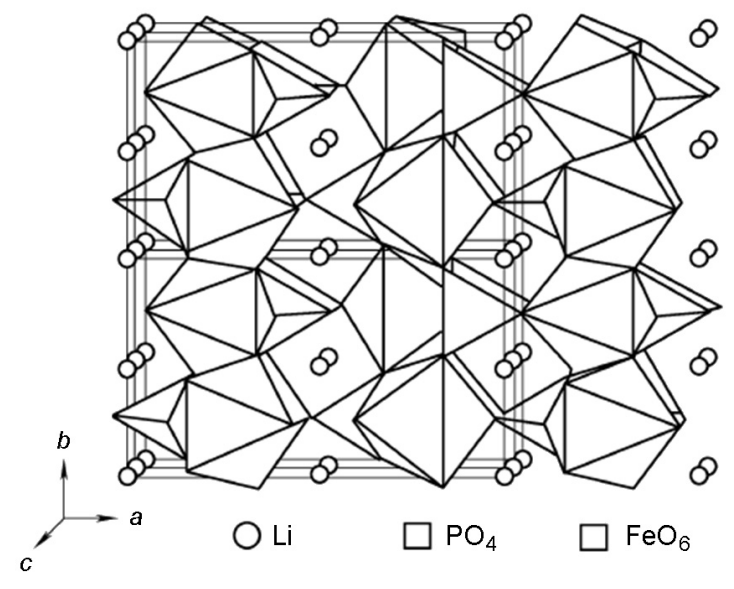

Fig. 2. Schematic diagram of $\mathrm{LiFePO}_{4}$

\subsection{Lithium iron phosphate battery}

The internal structure of the $\mathrm{LiFePO}_{4}$ battery is shown in Fig. 2. On the left is the olivine-structured $\mathrm{LiFePO}_{4}$ as the positive electrode of the battery. The aluminum foil is connected to the positive electrode of the battery. The middle is the polymer separator. It separates the positive electrode from the negative electrode, but the lithium ion $\mathrm{Li}+$ can pass and the electron e- cannot pass. The right side is composed of $\mathrm{A}$ battery negative electrode composed of carbon (graphite) is connected to the negative electrode of the battery by a copper foil. Between the upper and lower ends of the battery is the electrolyte of the battery, and the battery is hermetically sealed by a metal casing. When the $\mathrm{LiFePO}_{4}$ battery is charged, the lithium ion $\mathrm{Li}+$ in the positive

Table 1. Lithium-ion battery performance parameters

\begin{tabular}{|c|c|c|c|}
\hline Materials & $\begin{array}{l}\text { Fundamental performance } \\
\text { parameter }\end{array}$ & Advantage & Disadvantage \\
\hline $\mathrm{LiCoO}_{2}$ & $\begin{array}{l}\text { Theoretical capacity } 274 \mathrm{mAh} / \mathrm{g} \\
\text { practical capacity } 140 \mathrm{mAh} / \mathrm{g} \\
\text { working voltage } 2.5-4.2 \mathrm{~V}\end{array}$ & $\begin{array}{l}\text { charge-discharge } \\
\text { stabilization, High } \\
\text { specific capacity, Good } \\
\text { cycling performance }\end{array}$ & $\begin{array}{l}\text { Poisonous, pollute the } \\
\text { environment, shortage, } \\
\text { expensive }\end{array}$ \\
\hline $\mathrm{LiNiO}_{2}$ & $\begin{array}{l}\text { Theoretical capacity } 274 \mathrm{mAh} / \mathrm{g} \text {; } \\
\text { practical capacity } 190-210 \\
\mathrm{mAh} / \mathrm{g} \text {; working voltage } 2.5-4.2 \mathrm{~V}\end{array}$ & $\begin{array}{l}\text { Low self-discharge rate, } \\
\text { non-pollution, } \\
\text { Compatibility of high, } \\
\text { low cost }\end{array}$ & $\begin{array}{l}\text { Poor circulation } \\
\text { performance, Difficult } \\
\text { preparation, Thermal } \\
\text { stability survey }\end{array}$ \\
\hline $\mathrm{LiMn}_{2} \mathrm{O}_{4}$ & $\begin{array}{l}\text { Theoretical capacity } 148 \mathrm{mAh} / \mathrm{g} \text {; } \\
\text { practical capacity } 110-120 \\
\text { mAh/g; working voltage } 3.0-4.8 \mathrm{~V}\end{array}$ & $\begin{array}{l}\text { Mn abundant resources, } \\
\text { non-pollution, low cost, } \\
\text { easy preparation }\end{array}$ & $\begin{array}{l}\text { Low theoretical capacity, } \\
\text { High temperature } \\
\text { distortion }\end{array}$ \\
\hline $\mathrm{LiV}_{2}\left(\mathrm{PO}_{4}\right)_{3}$ & $\begin{array}{c}\text { Theoretical capacity } 197 \mathrm{mAh} / \mathrm{g} \text {; } \\
\text { working voltage } 3.0-4.8 \mathrm{~V}\end{array}$ & $\begin{array}{l}\text { Abundant raw materials, } \\
\text { low cost, non-pollution, } \\
\text { Good thermal stability }\end{array}$ & Low conductivity \\
\hline $\mathrm{LiFePO}_{4}$ & $\begin{array}{c}\text { Theoretical capacity } 170 \mathrm{mAh} / \mathrm{g} \text {; } \\
\text { practical capacity } 1650 \mathrm{mAh} / \mathrm{g} ; \\
\text { working voltage } 3.4 \mathrm{~V}\end{array}$ & $\begin{array}{l}\text { High stability, non- } \\
\text { pollution, low cost, long- } \\
\text { lived, memoryless }\end{array}$ & $\begin{array}{l}\text { Easily oxidized, Low } \\
\text { conductivity, Poor } \\
\text { circulation performance }\end{array}$ \\
\hline
\end{tabular}


electrode migrates toward the negative electrode through the polymer separator; during the discharge, the lithium ion $\mathrm{Li}+$ in the negative electrode migrates toward the positive electrode through the separator. Lithium-ion batteries are named after the lithium ions migrate back and forth during charging and discharging.

Compared with traditional lead-acid batteries and other lithium-ion batteries, $\mathrm{LiFePO}_{4}$ batteries have the advantages of higher safety performance, longer life, high temperature performance, large capacity, environmental protection, light weight, and no memory effect. The improved lithium iron phosphate ion battery has great development prospects for the large-scale energy storage of the power grid. At present, the 4MW energy storage demonstration power station built by China Southern Power Grid Corporation in Shenzhen is the iron phosphate ion battery.

\subsection{Preparation of improved $\mathrm{LiFePO}_{4}$} nanosheets

$\mathrm{LiFePO}_{4}$ nanosheets are prepared by solvothermal method. Ethylene glycol is used as solvent. The raw materials are $\mathrm{LiOH} \cdot \mathrm{H}_{2} \mathrm{O}$ (AR), $\mathrm{H}_{3} \mathrm{PO}_{4}$ (AR), $\mathrm{FeSO}_{4} \cdot 7 \mathrm{HO}$ (AR), and the molar ratio is $3:: 1$. The specific experimental steps are as follows:

(1) Weigh $0.045 \mathrm{~mol}$ of $\mathrm{LiOH} \cdot \mathrm{H}_{2} \mathrm{O}$ and add it to $25 \mathrm{~mL}$ ethylene glycol to stir it sufficiently.

(2) Weigh $0.015 \mathrm{~mol}$ of $85 \% \mathrm{H}_{3} \mathrm{PO}_{4}$ and slowly add it to the above solution to find a large amount of white precipitate.

(3) Take $0.045 \mathrm{~mol}$ of $\mathrm{FeSO}_{4} \cdot 7 \mathrm{HO}$ dissolved in $20 \mathrm{~mL}$ ethylene glycol, add dropwise to the above suspension, and stir vigorously for $30 \mathrm{~min}$ to $\mathrm{mix}$ the precursor thoroughly, and transfer the suspension to 100 $\mathrm{mL}$ reaction kettle. Then the temperature is raised to $180{ }^{\circ} \mathrm{C}$ for $18 \mathrm{~h}$.

(4) After the solvothermal process is completed and naturally cooled to room temperature, filtrate precipitate, washed several times with deionized water and 95\% ethanol, and dried under vacuum at $60^{\circ} \mathrm{C}$ overnight to obtain $\mathrm{LiFePO}_{4}$ nanosheets.

\subsection{Electrochemical performance study}

In order to study the effects of different morphologies of $\mathrm{LiFePO}_{4}$ on the electrochemical properties of the materials, constant-current charge-discharge tests are performed on the electrodes made of fabricated $\mathrm{LiFePO}_{4} / \mathrm{C}$ nanosheets, large aspect ratio nanosheets and nanorod composites, and

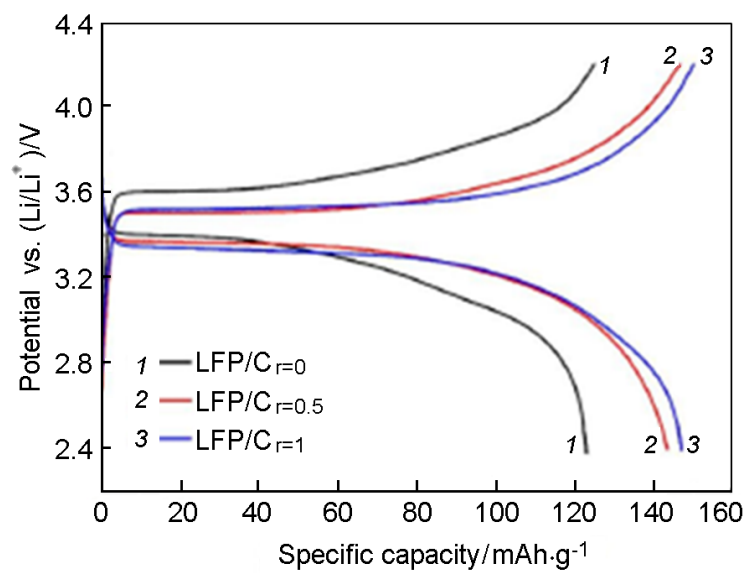

Fig.3. Initial charge and discharge curve of $\mathrm{LiFePO}_{4} / \mathrm{C}_{\mathrm{r}=0}$, $\mathrm{LiFePO}_{4} / \mathrm{C}_{\mathrm{r}=0.5}$ and $\mathrm{LiFePO}_{4} / \mathrm{C}_{\mathrm{r}=1}$.

lithium wafer is used as counter electrode. The voltage window during the test is 2.4 $\mathrm{V}-4.2 \mathrm{~V}$ for lithium potential, and the samples are tested at $0.5 \mathrm{C}, 1 \mathrm{C}, 2 \mathrm{C}$ and $5 \mathrm{C}$. When the magnification is greater than $1 \mathrm{C}$, $1 \mathrm{C}$ current density is used for charging, $2 \mathrm{C}$ and $5 \mathrm{C}$ currents density discharge. Fig. 3 shows the charge-discharge curves of electrodes prepared with $\mathrm{LiFePO}_{4} / \mathrm{C}_{\mathrm{r}=0}$, $\mathrm{LiFePO}_{4} / \mathrm{C}_{\mathrm{r}=0.5}$ and $\mathrm{LiFePO}_{4} / \mathrm{C}_{\mathrm{r}=1}$ materials at $1 \mathrm{C}$ rate. It can be seen from the figure that the $\mathrm{LiFePO}_{4} / \mathrm{C}_{\mathrm{r}}=\mathbf{0 . 5}$ and $\mathrm{LiFePO}_{4} / \mathrm{C}_{\mathrm{r}=\mathbf{1}}$ samples have significantly higher capacity than $\mathrm{LiFePO}_{4} / \mathrm{C}_{\mathrm{r}=0}$, and show a flatter and longer platform, as well as a smaller charge and discharge platform difference, indicating its small polarization potential is conducive to the reversibility of the electrode charge and discharge. This shows that the morphology has a close relationship with the properties of the material.

\section{Energy storage capacity optimization configuration model}

In this paper, an improved lithium iron phosphate battery is proposed for the optimization of energy storage and discharge capacity of grid, and the multi-objective function is established by considering the battery charge and discharge life, initial investment cost and system safety and stability.

\subsection{Objective function}

Objective 1: System tie line power fluctuations are lowest

$$
\min f_{1}=\frac{1}{N} \sum_{i=1}^{N}\left[P_{E S}(i)+P_{L}(i)+P_{G}(i)-\bar{P}\right]^{2}
$$


In formula 1 every symbol is expressed as follows:

$f$ - the volatility variance of the power of a typical intraday tie line;

$\bar{P}-$ the mean of system tie line fluctuation;

$P_{E}(i)$ - the system energy storage power during the period $i$;

$P_{L}(i)$ - the system load power during the period $i$;

$P_{G}(i)$ - system generated power during the period $i$.

Objective 2: Initial investment of energy storage system and spare capacity cost are lowest

$$
\min C=a P_{E S}+b E_{E S}+\lambda f_{1}
$$

In formula 2 every symbol is expressed as follows:

$P_{E S}$ - wind-PV-storage system power;

$E_{E S}$ - energy storage allocation capacity of wind-PV-storage system;

$a$ - unit power cost (yuan $/ \mathrm{kw}$ ), the energy storage for $\mathrm{LiFePO}_{4}$ battery is mainly the unit purchase cost of power converter PCS.

$b$ - unit capacity fee (yuan $/(\mathrm{kw} \cdot \mathrm{h})$ ), mainly for the unit capacity purchase cost of the battery.

\subsection{Restrictions}

$$
\left\{\begin{array}{l}
P_{E S} \leq P_{M} \\
E_{E S} \leq E_{M} \\
P_{E S} \geq P_{E S}(i) \\
E_{E S} \geq \frac{1}{S O C_{M}-S O C_{o}} \sum_{k=1}^{i} \delta(i) P_{E S} \Delta t
\end{array}\right.
$$

In formula 3 every symbol is expressed as follows:

$i$ - calculation period $(i=1,2, . . \mathrm{N})$;

$P_{M}, E_{M}$ - the maximum energy and capacity of energy storage allowed under limited conditions of the project;

$S O C_{M}$ - the highest state of charge allowed under the battery energy storage system;

$S O C_{O}$ - daily energy state of the battery energy storage system;

$P_{E S}(i)$ - charge and discharge power, when charging $P_{E S}(i)>0$, when discharging $P_{E S}(i) \leq 0$;

$\delta(i)$ - charging efficiency of the energy storage system;

$\frac{1}{\delta(i)}-$ efficiency during discharge of the energy storage system.

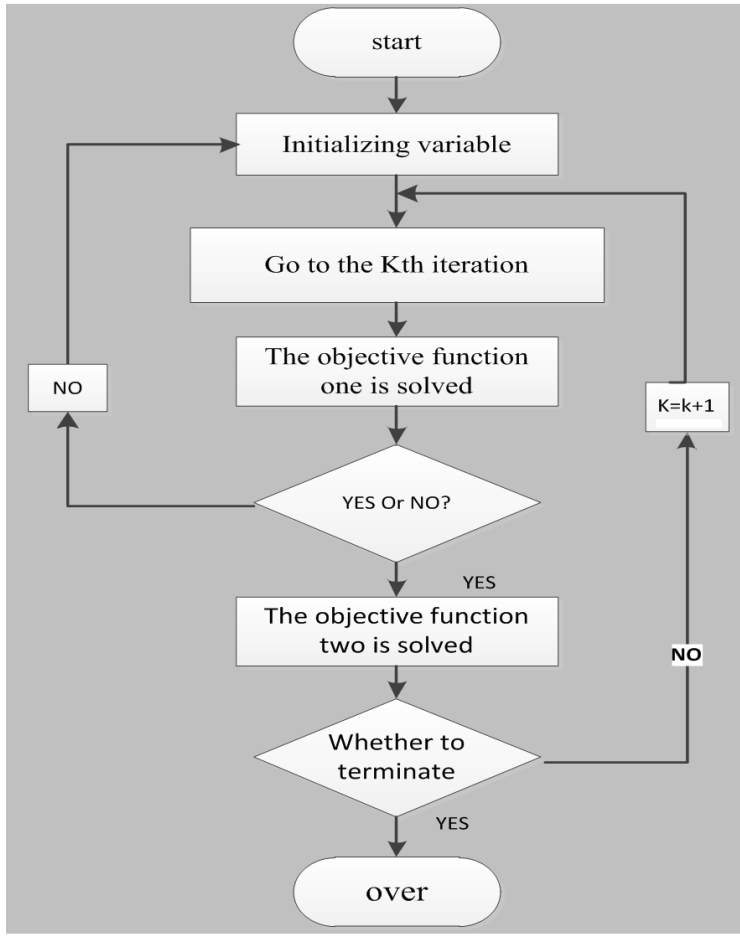

Fig. 4. Storage configuration process.

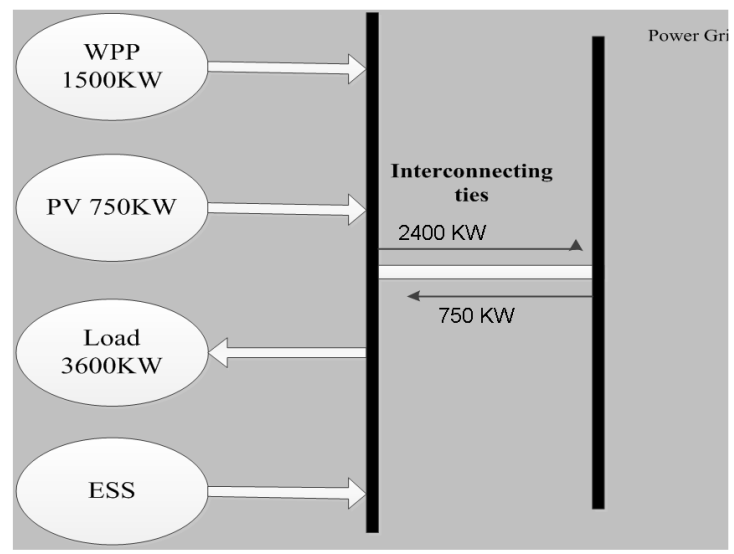

Fig. 5. Wind- photovoltaic-storage system structure.

$$
\left\{\begin{array}{l}
-P_{E S} \leq p_{E S}(i) \leq P_{E S} \\
S O C_{m} \leq S O C(i) \leq S O C_{M} \\
-P_{G 0} \leq p_{E S}(i)+p_{L}(i)-p_{G}(i) \leq P_{L 0}
\end{array}\right.
$$

In formula 4 every symbol is expressed as follows:

$P_{G 0}$ - the maximum power consumption allowed by the user;

$P_{L 0}$ - maximum reverse power allowed by the user.

\subsection{Solution}

The above analysis can be obtained. The objective functions are mixed integer programming and quadratic programming. The 


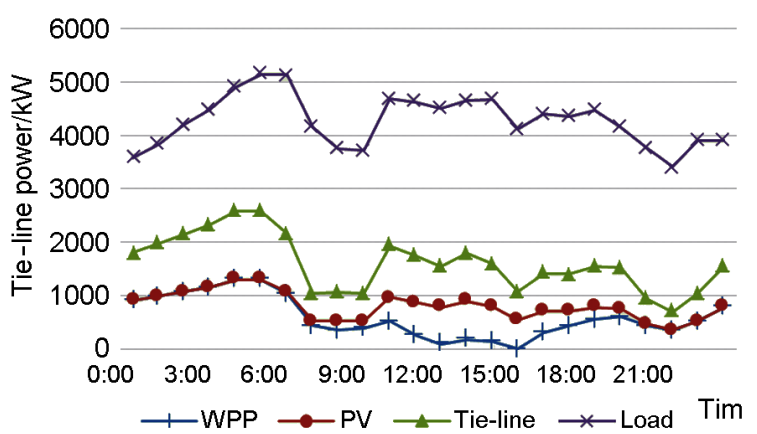

Fig. 6. The wind-PV-storage system parameter

Table 2. The wind-PV-storage system parameter

\begin{tabular}{|c|c|c||}
\hline Item & Index & Value \\
\hline wpp & Maximum output/kw & 1290 \\
\hline PV & Maximum output/kw & 720 \\
\hline Tie-line & Maximum/kw & 1290 \\
\hline & Power fluctuation & 946 \\
\hline Load & Maximum output/kw & 3112 \\
\hline & Valley-to-peak/kw & 1779 \\
\hline
\end{tabular}

CPLEX solver developed by IBM can be used to quickly solve mathematical programming problems such as general linear programming, mixed integer programming, and quadratic programming. Add to Matlab software, realize the call of CPLEX solver in matlab software, use Yalmip modeling toolbox, the modeling process includes four parts, construct decision variables, increase constraints, configure algorithm and build model, and call CPLEX to solve, the steps are shown in Fig. (4).

\section{Case analysis}

\subsection{Basic data}

The wind power storage system consists of wind power, photovoltaic, lithium iron phosphate battery energy storage and load, of which wind power installed capacity is $1500 \mathrm{KW}$, photovoltaic installed capacity is $750 \mathrm{KW}$, maximum load is $3600 \mathrm{KW}$, the maximum power limit of the tie line is $2400 \mathrm{KW}$, and the reverse power is $750 \mathrm{KW}$. The system structure diagram is as shown in Fig. 5.

Here, select a typical daily wind power, photovoltaic output curve, load curve and power fluctuations, as shown in Table 2 and Fig. 6. In the Wind-PV- Storage system, the wind energy is rich in nighttime resources, and the winter is better during the day and winter, and the summer resources are less; the illumination is just the opposite, the

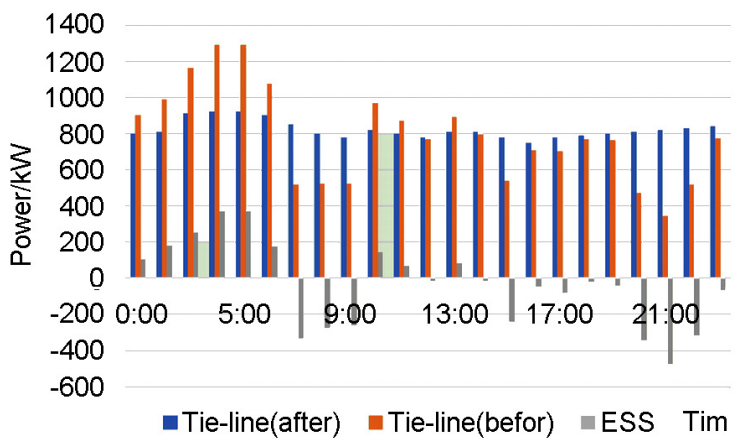

Fig. 7. Tie line power with energy storage system

Table 3. Comparison of the Tie-line power with and without storage

\begin{tabular}{||c|c|c||}
\hline \hline Tie-line power & Index & Value \\
\hline $\begin{array}{c}\text { Tie-line } \\
\text { power(befor) }\end{array}$ & $\begin{array}{c}\text { Maximum } \\
\text { output/kw }\end{array}$ & 1290 \\
\cline { 2 - 3 } & $\begin{array}{c}\text { Fluctuating } \\
\text { value/kw }\end{array}$ & 946 \\
\cline { 2 - 3 } & Variance & 79029 \\
\hline $\begin{array}{c}\text { Tie-line } \\
\text { power(after) }\end{array}$ & $\begin{array}{c}\text { Maximum } \\
\text { output/kw }\end{array}$ & 920 \\
\cline { 2 - 3 } & $\begin{array}{c}\text { Fluctuating } \\
\text { value/kw }\end{array}$ & 130 \\
\cline { 2 - 3 } & variance & 1110 \\
\hline
\end{tabular}

winter is rich in daytime resources, and there is no light at night. Industrial loads are relatively high during the day and relatively low at night. Parameter $a, b, \lambda$ are respectively $500 \mathrm{yuan} / \mathrm{kw}, 2000 \mathrm{yuan} / \mathrm{kwh}$ and $15000 \mathrm{yuan} / \mathrm{kw} ; S O C_{m}, S O C_{M}, S O C_{0}$ are respectively $0.2,1.0,0.5 ; p_{L 0}, p_{G 0}$ are $1600 \mathrm{kw}, 500 \mathrm{kw}$.

\subsection{Simulation result}

According to the values of the parameters in the simulation example, the energy storage configuration flow chart of the multi-objective decision calculates the required power capacity of the energy storage system. The power line of the tie line after the storage capacity of the lithium-ion battery is configured is shown in Fig. 7.

It is shown in Fig. 7 and Table 3 after adding energy storage, the typical daily tie line power curve does not exceed the tie line power limit, and the fluctuation range is reduced from 946 to 130 , and the fluctuation suppression is obvious. Fig. 7 shows the results of energy storage optimization configuration, in which the night wind output is larger, the stored energy of the con- 
figuration is up to $370 \mathrm{kw}$, lithium ion battery energy storage; although there is photovoltaic output during the day, but the wind power output is small, making night storage Lithium-ion batteries release energy.

\section{Conclusions}

In this paper, the dynamic square lithium iron phosphate battery was used as the research object. The structural stability, electrochemical properties and surface morphology of the positive and negative electrodes were studied in depth. The solvothermal method was used to prepare the improved lithium iron phosphate ion nanosheets. The constant current charge and discharge tests show that the capacity of $\mathrm{LiFePO}_{4} / \mathrm{C}_{\mathrm{r}}=\mathbf{0 . 5}$ and $\mathrm{LiFePO}_{4} / \mathrm{C}_{\mathrm{r}=1}$ samples was significantly higher than that of $\mathrm{LiFePO}_{4} / \mathrm{C}_{\mathrm{r}=0}$, and demonstrated a flatter and longer platform, as well as smaller difference in charge and discharge platform, which indicates that its small polarization potential is conducive to the reversibility of charge and discharge of the electrode and the improved morphology has a close relationship with its charge and discharge life.
Meanwhile, the paper constructed an improved lithium iron phosphate battery for energy storage and discharge capacity optimization model, fully considering the initial investment cost and system safety and stability of the improved lithium iron phosphate battery. The multi-objective functions are mutually constrained, and the stability and economic performance of the system is weighed to solve the energy storage capacity configuration that makes the system perform optimal.

\section{References}

1. Yu Bo, JAppl. Mathem., 2011, 1 (2011).

2. Wang Ling, Gao Pengzhao, J. Bull. Chin. Ceramic Soc., 32, 1 (2013).

3. Zhao Xinbing, Xie Jian, J. Mech. Engin., 2017, 69 (2007).

4. Jiang Kai, Li Haomiao, J.Automat. Electric Power System, 37, 47 (2013).

5. Yang Shaoshuai, Luo Pingping, J. Modern Electric Power, 36, 37 (2019).

6. Li Jianlin, Guo,Binqi, J. Trans. China Electr. Soc., 33, 1189 (2018).

7. Zheng Le, Hu Wei, J. Procee. CSEE., 34, 2533 (2014). 